\title{
Zoospore interspecific signaling promotes plant infection by Phytophthora
}

\author{
Ping Kong ${ }^{1 *}$, Brett M Tyler ${ }^{2}$, Patricia A Richardson ${ }^{1}$, Bobby WK Lee ${ }^{3}$, Zhaohui S Zhou ${ }^{3}$ Chuanxue Hong
}

\begin{abstract}
Background: Oomycetes attack a huge variety of economically and ecologically important plants. These pathogens release, detect and respond to signal molecules to coordinate their communal behaviors including the infection process. When signal molecules are present at or above threshold level, single zoospores can infect plants. However, at the beginning of a growing season population densities of individual species are likely below those required to reach a quorum and produce threshold levels of signal molecules to trigger infection. It is unclear whether these molecules are shared among related species and what their chemistries are.

Results: Zoospore-free fluids (ZFF) from Phytophthora capsici, P. hydropathica, P. nicotianae (ZFFnic), P. sojae (ZFFsoj) and Pythium aphanidermatum were cross tested for stimulating plant infection in three pathosystems. All ZFFs tested significantly increased infection of Catharanthus roseus by P. nicotianae. Similar cross activities were observed in infection of Lupinus polyphyllus and Glycine max by P. sojae. Only ZFFnic and ZFFsoj cross induced zoospore aggregation at a density of $2 \times 10^{3} \mathrm{ml}^{-1}$. Pure autoinducer-2 (Al-2), a component in ZFF, caused zoospore lysis of $P$. nicotianae before encystment and did not stimulate plant infection at concentrations from 0.01 to $1000 \mu \mathrm{M}$. P. capsici transformants with a transiently silenced $\mathrm{Al}-2$ synthase gene, ribose phosphate isomerase (RPI), infected Capsicum annuum seedlings at the same inoculum concentration as the wild type. Acyl-homoserine lactones (AHLs) were not detected in any ZFFs. After freeze-thaw treatments, ZFF remained active in promoting plant infection but not zoospore aggregation. Heat treatment by boiling for $5 \mathrm{~min}$ also did not affect the infectionstimulating property of ZFFnic.

Conclusion: Oomycetes produce and use different molecules to regulate zoospore aggregation and plant infection. We found that some of these signal molecules could act in an inter-specific manner, though signals for zoospore aggregation were somewhat restricted. This self-interested cooperation among related species gives individual pathogens of the same group a competitive advantage over pathogens and microbes from other groups for limited resources. These findings help to understand why these pathogens often are individually undetectable until severe disease epidemics have developed. The signal molecules for both zoospore aggregation and plant infection are distinct from $\mathrm{Al}-2$ and $\mathrm{AHL}$.
\end{abstract}

\section{Background}

Zoosporic plant pathogens in the phylum Oomycota of the Stramenopila kingdom include hundreds of devastating species that attack a broad range of economically important agricultural and ornamental crops as well as forest tree species $[1,2]$. These oomycetes, including Phytophthora and Pythium species, use motile zoospores

\footnotetext{
* Correspondence: pkong@vt.edu

'Department of Plant Pathology, Physiology and Weed Science, Virginia Polytechnic Institute and State University, Virginia Beach, VA 23455-3363, USA

Full list of author information is available at the end of the article
}

for dispersal and plant infection [3-5]. Plant infection by zoosporic pathogens is often effective in nature despite the fact that the population density in primary inoculum sources is relatively low [6-9]. This has led to differing theories with regard to density-dependent zoospore behaviors and plant infection [10-17]. A recent study with Phytophthora nicotianae showed that plant infection may be regulated through zoosporic extracellular products in zoospore-free fluid (ZFF) which can promote infection by a single zoospore [18]. This indicates that the physical presence of the threshold density of zoospores at an infection site is not strictly required,
Ciomed Central

() 2010 Kong et al; licensee BioMed Central Ltd. This is an Open Access article distributed under the terms of the Creative Commons Attribution License (http://creativecommons.org/licenses/by/2.0), which permits unrestricted use, distribution, and reproduction in any medium, provided the original work is properly cited. 
and plant infection can be initiated efficiently through chemical communication by the population. However, it is not clear how such a process is carried out by a pathogen at its naturally occurring low population density, which would be unlikely to produce adequate levels of functional signals unless these signals were also produced by other organisms and readily accessible in the environment.

$\mathrm{Ca}^{2+}$ and autoinducer 2 (AI-2), two widespread and non-specific signaling molecules, are known to be produced by zoosporic oomycetes [19-21]. $\mathrm{Ca}^{2+}$ plays a central role in autonomous encystment, adhesion and germination of cysts in zoosporic oomycetes $[3,10,14,22-24]$. However, it is not considered to be an autoinducer because $\mathrm{Ca}^{2+}$ does not directly trigger cooperative behaviors of zoospores and acts more like a secondary messenger [18]. AI-2 was first detected in bacteria and is utilized for metabolism and quorum sensing in bacteria [25-27]. In the latter process, bacteria respond to these released signaling molecules or autoinducers to coordinate their communal behavior. Eukaryotes including oomycetes can also produce AI-2 or AI2-like activities [21,28-30] although they do not use the LuxS pathway that most bacteria use [31,32]. Instead, AI-2 is formed spontaneously from D-ribulose-5-phosphate that is synthesized in these eukaryotes from pentose-phosphates by ribose phosphate isomerase (RPI) in the pentose-phosphate pathway [28]. AI-2 has been proposed as a universal signaling molecule in bacteria based on its role in inter-species signaling and postulated cross-kingdom communication [33-40]. However, the function of AI-2 in eukaryotes has not been established.

The aim of this study was to investigate the nature of signal molecules in ZFF. Specifically, we identified interspecific signaling activities of ZFF from four Phytophthora species and one Pythium species. We also assessed the potential of AI-2 along with another known bacterial autoinducer as signal molecules for communication among zoosporic species.

\section{Results and Discussion}

\section{ZFF interspecific stimulation of zoosporic infection}

Zoospore-free fluids were prepared from suspensions at a density of $10^{4}$ zoospores $\mathrm{ml}^{-1}$ or higher of Phytophthora nicotianae (ZFFnic), P. capsici (ZFFcap), P. hydropathica (ZFFhyd), P. sojae (ZFFsoj) and Pythium aphanidermatum (ZFFaph) and evaluated in three phytopathosystems. Inoculation of annual vinca (Catharanthus roseus) with suspensions containing an average of one zoospore of $P$. nicotianae in any of the four ZFFs resulted in significantly higher infection $(P<0.001)$ compared to the control (SDW). Specifically, percentages of sites infected were $39 \%, 21 \%, 11 \%$, and $15 \%$ for ZFFaph, ZFFhyd, ZFFnic, and ZFFsoj, respectively compared to $3 \%$ for SDW (Figure 1A). Similarly, ZFFaph, ZFFhyd, ZFFnic and ZFFsoj stimulated infection of lupine (Lupinus polyphyllus) by P. sojae (Figure 1B), while ZFFcap and ZFFsoj stimulated infection of soybean (Glycine max) by P. sojae (Figure 1C). These results indicate that ZFF from the different Phytophthora species and Py. aphanidermatum contained one or more signals stimulating zoosporic infection by $P$. nicotianae and P. sojae that are active across species boundaries.

Many plants are attacked by multiple oomycete species [1]. The ability of oomycete pathogens to benefit from the presence of related (or unrelated) species is presumably a selective advantage, especially if the diverse pathogens are competing for a limited resource (i.e. the host plant tissue) and/or the initial population density of each individual pathogen population is low. Such self-interested cooperation may have further advantages if the effector molecules released by each pathogen species have complementary or synergistic capabilities for suppressing plant defenses.

\section{ZFF inter-specific regulation of zoospore aggregation}

To determine whether ZFF may also have cross-species activity in regulating zoospore aggregation, fresh zoospores of P. nicotianae and P. sojae at a concentration (2 $\times 10^{3} \mathrm{ml}^{-1}$ ) below normal aggregation thresholds (approx. $10^{6} \mathrm{ml}^{-1}$ ) were cross incubated in multiwell plates with ZFFsoj or ZFFnic and compared with those in SDW. Zoospores of $P$. nicotianae in ZFFsoj and those of $P$. sojae in ZFFnic aggregated (Figure 2C and 2G) as if they were in ZFF produced by their own species. As expected, zoospores of neither species aggregated in SDW (Figure 2D and 2H). ZFFcap and ZFFaph did not stimulate zoospore aggregation by $P$. nicotianae or $P$. sojae zoospores. However, they did stimulate germination of cysts of both P. nicotianae and P. sojae (Figure 2A, B, E, F), which may explain their activity in promoting plant infection (Figure 1). It was interesting that zoospores of $P$. capsici did not aggregate even at a density of $10^{6}$ zoospores $\mathrm{ml}^{-1}$. These results indicate that the signal(s) involved in aggregation are somewhat species-restricted and may be different from those mediating the infection process.

\section{Al-2 is not involved in zoospore communication and promotion of plant infection}

To test whether AI-2 may be involved in zoospore communication and promotion of plant infection, purified AI-2 was used in place of ZFF. AI-2 was tested at a wide concentration range of $0.01 \mu \mathrm{M}-1 \mathrm{mM}$ for its effects on $P$. nicotianae zoospore behaviors and plant infection; the concentration of AI-2 in ZFF was estimated to be less than $2 \mu \mathrm{M}$ [21]. Under the microscope, 

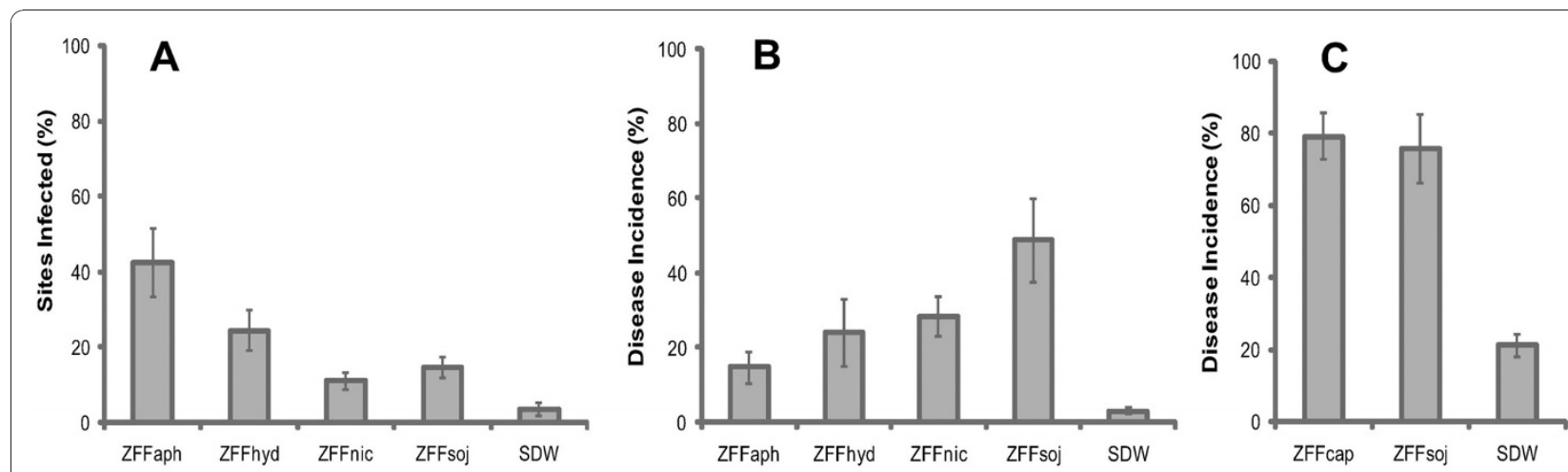

Figure 1 Cross effects of zoospore-free fluid (ZFF) from different pythiaceous species on plant infection by Phytophthora sp. ZFF was prepared from zoospore suspensions of Py. aphanidermatum (ZFFaph) and P. hydropathica (ZFFhyd) at $3 \times 10^{4} \mathrm{ml}^{-1}$, and from P. capsici (ZFFcap), P. nicotianae (ZFFnic) and P. sojae (ZFFsoj) at $5 \times 10^{4} \mathrm{ml}^{-1}$, respectively. Each ZFF was used as diluent to prepare inocula at a final density of 100 zoospores $\mathrm{ml}^{-1}$ (or approximately 1 per 10- $\mu \mathrm{l}$ drop) and evaluated against sterile distilled water (SDW) in three pathosystems. (A) Catharanthus roseus cv. Little Bright Eye $\times$ P. nicotianae. Ten drops of inoculum were applied to the underside of each detached leaf at different sites and infection was assessed after 3 -day incubation at $23^{\circ} \mathrm{C}$. Each column is a mean percentage of sites diseased $(\mathrm{N}=54)$. (B) Lupinus polyphyllus $\times P$. sojae. Two drops of inoculum were applied to each cotyledon and disease was assessed after 5 -day incubation at $23^{\circ} \mathrm{C}$. Each column is a mean percentage of dead seedlings $(\mathrm{N}=30)$. (C) Glycine max $\mathrm{cv}$. Williams $\times$ P. sojae. Two drops of inoculum were applied to hypocotyl of each seedling and disease was assessed after 4-day incubation at $26^{\circ} \mathrm{C}$. Each column is a mean percentage of dead seedlings $(N=6)$. Bars represent standard deviation in each case.

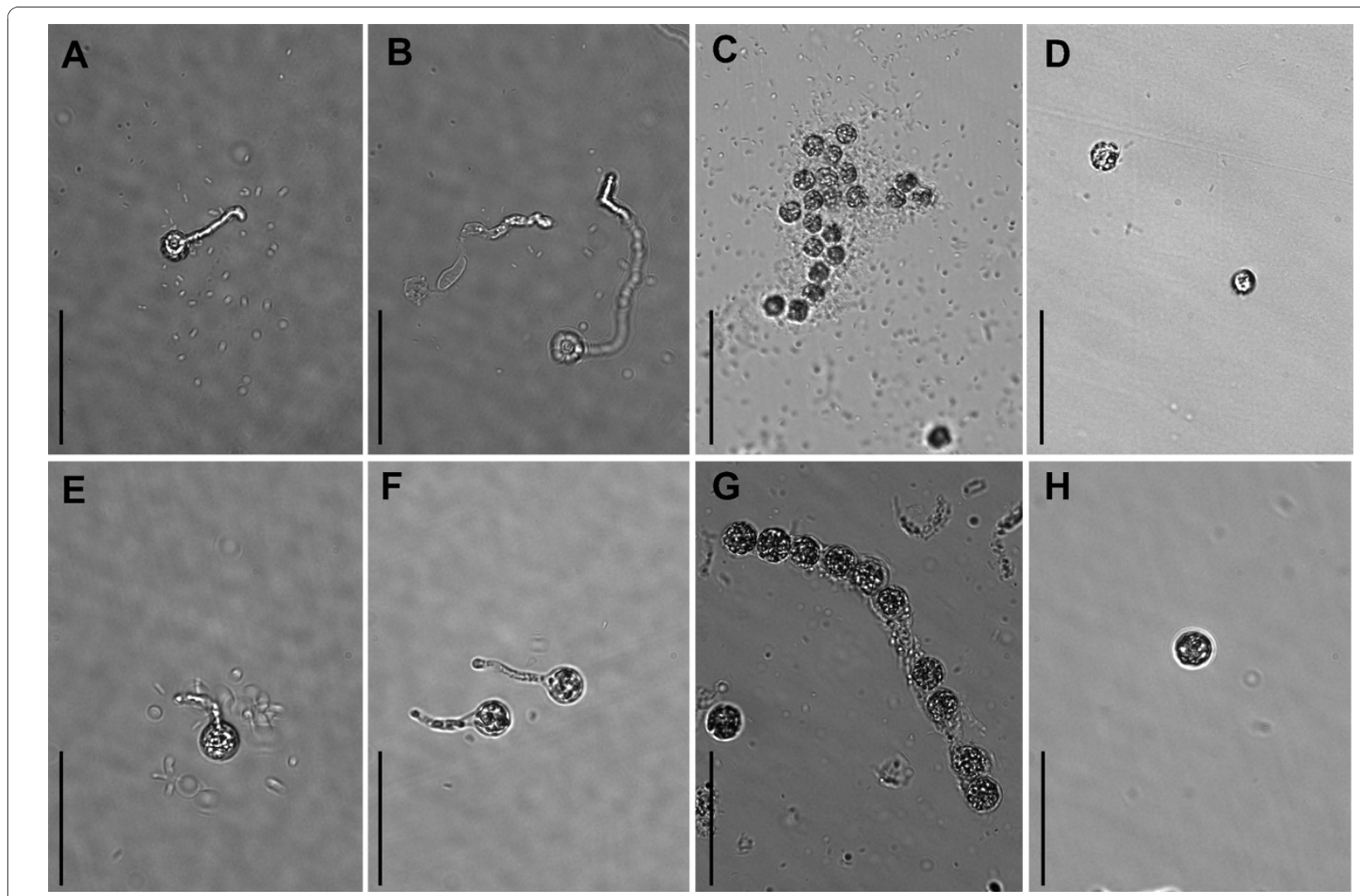

Figure 2 Effect of zoospore-free fluid (ZFF) on aggregation of Phytophthora nicotianae and Phytophthora sojae zoospores. Zoospores of P. nicotianae $\left(2 \times 10^{3} \mathrm{ml}^{-1}\right)$ were incubated in ZFF of (A) Py. aphanidermatum, (B) P. capsici, (C) P. sojae, and (D) sterile distilled water (SDW). Zoospores of $P$. sojae $\left(2 \times 10^{3} \mathrm{ml}^{-1}\right)$ were incubated in ZFF of (E) Py. aphanidermatum, (F) P. capsici, (G) P. nicotianae and (H) SDW. Images were captured 18 hours after incubation at $23^{\circ} \mathrm{C}$. Bar $=50 \mu \mathrm{m}$. 
Table 1 Effect of purified Al-2 on encystment and germination of P. nicotianae zoospores after overnight incubation at $23^{\circ} \mathrm{C}$

\begin{tabular}{ccccccccc}
\hline $\begin{array}{l}\text { Conc. of } \\
\text { Al-2 }(\boldsymbol{\mu M})\end{array}$ & No. of cysts & $\begin{array}{c}\text { No. of } \\
\text { germinating } \\
\text { cysts }\end{array}$ & $\begin{array}{c}\text { No. of empty } \\
\text { cells }\end{array}$ & $\begin{array}{c}\text { No. of lysed } \\
\text { zoospores }\end{array}$ \\
\hline & $\mathbf{M}^{\mathbf{b}}$ & $\mathbf{S t d}^{\mathbf{b}}$ & $\mathbf{M}$ & Std & $\mathbf{M}$ & Std & $\mathbf{M}$ & Std \\
\cline { 2 - 9 } & 5 & 0.3 & 12 & 2.3 & 39 & 1.0 & 1 & 3.8 \\
0 & 10 & 0.3 & 7 & 0.5 & 22 & 1.3 & 17 & 1.0 \\
0.1 & 5 & 0.5 & 4 & 0.8 & 22 & 0.8 & 25 & 0.5 \\
1 & 2 & 0.3 & 0 & 0.0 & 21 & 1.8 & 33 & 2.0 \\
10 & 11 & 0.5 & 0 & 0.0 & 22 & 2.1 & 19 & 2.5 \\
100 & 20 & 1.0 & 0 & 0.0 & 0 & 0.0 & 36 & 1.0 \\
1000 & 14 & 1.3 & 0 & 0.0 & 0 & 0.0 & 42 & 1.3 \\
\hline
\end{tabular}

${ }^{a}$ Difference between the total number of zoospores (56 \pm 4 ) in SDW and those countable in $\mathrm{Al}-2$ at each concentration.

${ }^{\mathrm{b}} \mathrm{M}$ is the mean from 12 replicate fields (at $100 \mathrm{x}$ ) of three assays. Std is the standard deviation.

an increased number of zoospores treated with AI-2 lysed before encystment and failed to germinate as the AI-2 concentration was increased (Table 1). Zoospore aggregation was not observed at any concentration tested. In infection experiments with annual vinca, AI-2 did not promote single zoospore infection at any concentration. Interestingly, AI-2 induced hypersensitive response (HR)-like micro-lesions on the inoculated sites at $100 \mu \mathrm{M}$ and higher. These results indicated that AI-2 was not responsible for any of the zoospore signals found in ZFF.

As a complementary test for the ability of AI-2-like molecules to mediate zoospore communication and promote plant infection, we cloned and silenced the ribose phosphate isomerase (RPI) gene of $P$. capsici. RPI converts ribose-5-phosphate to ribulose-5-phosphate, which can spontaneously convert to AI-2-like molecules under physiological conditions [28]. RPI was proposed to be responsible for production of AI-2-like molecules in zoosporic pathogens [21]. To silence the RPI gene of $P$. capsici, protoplasts of $P$. capsici were treated with RPI dsRNA. If RPI had a role in production of zoospore signaling molecules, $R P I$-silenced lines would be expected to require much higher zoospore concentrations to infect plants than the wild type due to reduced or blocked AI-2 production by the inocula. One third of the $48 \mathrm{~T}_{0}$ lines regenerated 7 days after dsRNA exposure showed no or decreased expression with RPI compared to the endogenous control actin detected using RT-PCR. Half of these silenced or down regulated RPI lines retained the same reduced transcript levels two weeks after being transferred to fresh media $\left(T_{1}\right)$ (Figure $3 E$ ). Five $T_{1}$ lines were simultaneously tested for zoospore threshold for infection. The resulting disease incidences were very similar to those produced by wild type $P$. capsici at zoospore inoculum concentrations

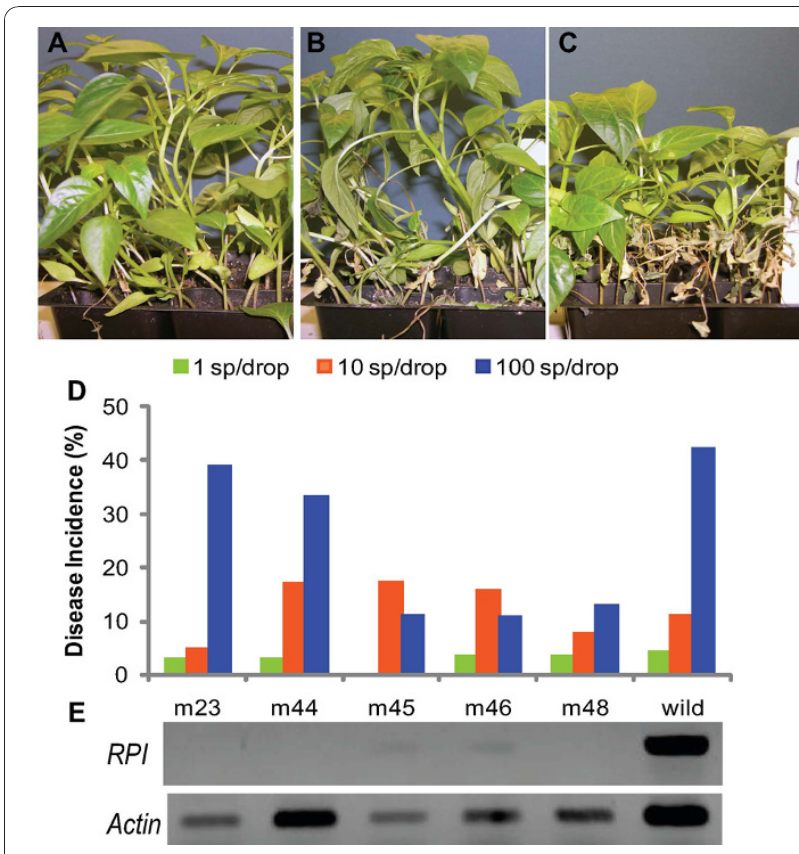

Figure 3 Infection of Capsicum annuum cv. California Wonder by wild or gene-silenced Phytophthora capsici. Two 10- $\mu$ l drops of zoospore suspension at $10^{2}, 10^{3}$ or $10^{4} \mathrm{ml}^{-1}$ were applied to hypocotyl of pepper seedling and disease was assessed after 5-day incubation at $26^{\circ} \mathrm{C}$. (A, B, C) Symptoms on seedlings inoculated with wild type at $10^{2}, 10^{3}$ and $10^{4}$ zoospores $\mathrm{ml}^{-1}$, respectively. (D) Disease incidence of seedlings inoculated with wild or ribose phosphate isomerase (RPI) gene-silenced strains $(\mathrm{N}=6)$. (E) RPI expression in transiently silenced lines $\left(T_{1}\right)$ on day 14 after transfer from7 day- old regenerated transformants $\left(T_{0}\right)$ treated with dsRNA as indicated by the RT-PCR products of RPI compared with equal amounts of endogenous control actin from the $T_{1}$ mutant RNA.

ranging from $10^{2}$ to $10^{4} \mathrm{ml}^{-1}$ (Figure 3A-D) $(P=0.705 ; P$ $=0.065 ; P=0.598$, respectively). These results indicate that RPI silencing had no significant impact on zoospore communication during infection. The ZFF activity of the silenced lines was not evaluated due to the transient nature of dsRNA-mediated silencing [41] and insufficient numbers of $\mathrm{T}_{1}$ zoospores for ZFF production. Nevertheless, these findings are consistent with the conclusion that AI-2-like molecules that might be produced via the action of RPI are not required for infection at low inoculum densities.

The function of AI-2-like activities produced by zoosporic oomycetes remains unclear although it regulates bacteria quorum sensing [21]. Two-way communication has been observed between eukaryotes and bacteria such as Leguminosae and bacterial rhizobia [42] and between mycorrhiza and Streptomyces [43]. In the former case, plants release flavonoids that bind LysR-family transcriptional regulators in the bacteria, leading to the production of Nod factor that facilitates nitrogen fixation. In the latter case, fungal metabolites stimulate the bacteria to 
produce auxofuran which promotes growth of both the fungus and the host plants. Perhaps zoosporic oomycetes utilize AI-2 to attract quorum sensing bacteria which subsequently release factors that facilitate plant infection. Indeed, bacteria have been shown to benefit sporangium production by zoosporic oomycetes [44].

\section{Involvement of other molecules in ZFF activity}

Acyl-homoserine lactones (AHLs), or bacterial autoinducer 1 , are utilized by zoospores of the green seaweed Enteromorpha (Ulva) for communication in the search for settlement surfaces [45]. A bioassay was performed using the Agrobacterium tumefaciens reporter strain KYC55/pJZ410/pJZ384/pJZ372 [46] in plate and spectrophotometric tests to determine whether this molecule is present in ZFF. LacZ activity was detected in all four positive control plates at $\mathrm{nM}$ concentrations of AHL but not in ZFFnic or ZFFsoj prepared from zoospore suspensions at $>10^{4}$ spores $\mathrm{ml}^{-1}$ nor in concentrated extracts from them obtained with ethyl acetate. These results indicate that zoospores from these oomycete species do not produce AHLs which therefore cannot be responsible for any ZFF activity.

\section{Temperature sensitivity of ZFF activities}

To begin to characterize the signal molecules in ZFF we tested their temperature sensitivity. ZFFnic did not stimulate zoospore aggregation after a freeze-thaw or heat treatment, suggesting that the molecule promoting this behavior may be a protein or lipoprotein that is sensitive to heat and freezing. On the other hand, freeze-thaw did not affect the activity of ZFFnic in promoting plant infection by zoospores (data not shown). In addition, ZFFnic boiled for 5 minutes remained as active as the untreated in promoting infection (Figure 4), indicating that the molecule which stimulates plant infection is temperature insensitive and different from that involved in aggregation.

\section{Conclusion}

This study demonstrated inter-specific activities of zoospore extracellular products in promoting zoospore aggregation and plant infection by Phytophthora. Zoosporic oomycetes contain hundreds of species and are widespread in irrigation water and plant production fields. However, specific populations detected in primary inoculum sources are not in sufficient numbers to produce signals that could promote plant infection. Inter-specific chemical communication (probably selfinterested) as a strategy used by zoosporic pathogens for effective plant infection provides insights into the destructiveness of these pathogens and the importance of the microbial community and the environment in the infection process.
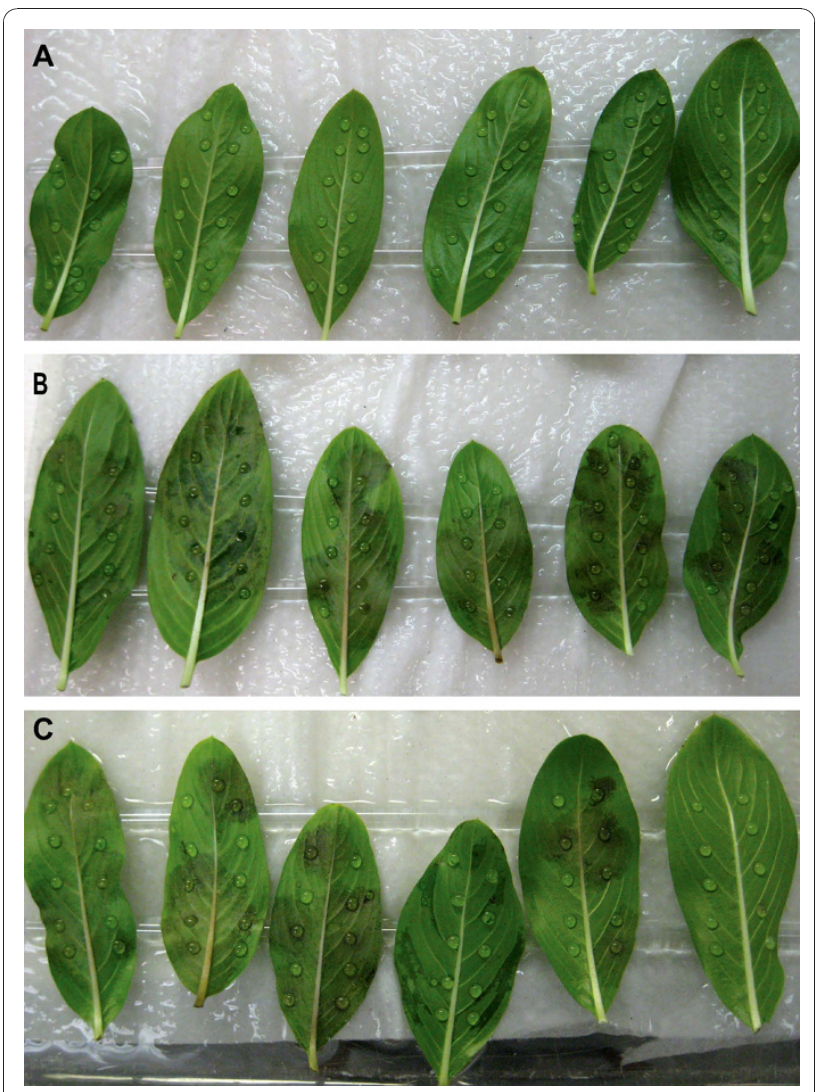

Figure 4 Zoospore-free fluid (ZFF) stimulation of Phytophthora infection is unaffected by heat treatment. Each leaf of

Catharanthus roseus cv. Little Bright Eye was inoculated with twelve $10-\mu l$ drops of inoculum of P. nicotianae at approximately one zoospore per drop. Zoospores were suspended in (A) sterile distilled water, (B) untreated ZFF from the same species at $5 \times 10^{5}$ zoospores $\mathrm{ml}^{-1}$ and (C) heat-treated ZFF. Disease symptoms were photographed after 3 -day incubation at $23^{\circ} \mathrm{C}$.

AI-2 was excluded as a signal for communal behavior in zoosporic oomycetes, despite its detection in ZFF and widespread presence in the environment. AI-2 synthase RPI and purified AI-2 both were not required for regulation of zoospore aggregation and infection. AHLs also were excluded because of their absence in ZFF. Thus, zoosporic oomycetes may use completely different chemicals from bacteria for quorum sensing. Analysis of ZFF revealed that functional signals controlling zoospore aggregation and plant infection differ in molecular composition. The former is not temperature labile and acts upon a restricted number of species while the latter is heat labile and non-speciesspecific. Identifying these molecules will facilitate our understanding of the mechanisms underlying natural plant infection by these pathogens and may lead to innovative control strategies. 


\section{Methods}

\section{Zoosporic oomycetes and culture conditions}

Four Phytophthora species, P. nicotianae (1B11), P. sojae (28G4), P. capsici (24F4), P. hydropathica (37E6) and one Pythium species Py. aphanidermatum (18H7) were used in this study. These species are distinct in morphology and genetics $[2,47]$. Specifically, P. nicotianae, P. capsici and Py. aphanidermatum have broad host ranges while $P$. sojae has a restricted host range, generally infecting only soybeans and lupines. P. hydropathica (37E6) originated from irrigation water and is a pathogen of nursery plants [48]. The isolates were maintained on clarified vegetable juice agar (CV8A) medium [49] at $23^{\circ} \mathrm{C}$.

\section{Preparation of zoospore-free fluid}

Zoospore-free fluid (ZFF) from a particular species is designated with an abbreviated species name. For example, ZFFnic represents ZFF from a $P$. nicotianae zoospore suspension. ZFF was prepared from nutrientdepleted zoospore suspensions starting with sporangium induction as described previously $[18,21]$. Specifically, prior to sporangium production, $P$. sojae and Py. aphanidermatum were cultured for 3-4 days and the other species were cultured for 1-2 wk in 10\% CV8 broth. After nutrient depletion (medium removal and water rinses), the mycelial mats were further incubated for 16 $18 \mathrm{~h}$ for P. sojae and Py. aphanidermatum, 2-3 days for $P$. capsici and one week for the other species under fluorescent light at $23^{\circ} \mathrm{C}$ to obtain a desired number of sporangia. To induce zoospore release, the mats with sporangia were flooded with chilled SDW and kept under lights until the desired zoospore density was reached. ZFF was obtained by passing a zoospore suspension through a $0.2 \mu \mathrm{m}$ pore-size filter after vortexing for $2 \mathrm{~min}$. ZFF was used fresh or stored at $-20^{\circ} \mathrm{C}$. Freezing destroyed the aggregation-promoting activity of ZFF, but not its infection-promoting activity.

\section{Phytopathosystems, plant growth conditions, inoculum preparation and inoculation}

Four phytopathosystems, $P$. nicotianae $\times$ annual vinca (Catharanthus roseus cv. Little Bright Eye), P. sojae $\times$ lupine (Lupinus polyphyllus), P. sojae $\times$ soybean (Glycine max cv. Williams) and P. capsici $\times$ pepper (Capsicum annum cv. California Wonder) were used.

Annual vinca plants were prepared in the greenhouse where 4-wk old seedlings were grown in pine bark with fertilizer for 4-6 wk. Soybean and pepper seedlings were prepared by growing 9 seeds per pot in sterilized Soilless Potting Mix (Schultz Professional) supplied with fertilizer and fungicide for 2 and 4 weeks, respectively, in the greenhouse. For lupine plants, 10 germinated seeds per styrofoam cup were grown in sterilized vermiculite
(Whittemore Com) and fertilizer solution 20-20-20 (Scotts) for 2 wk in the growth chamber.

Single-zoospore inocula with an average concentration of one zoospore per drop $(10 \mu \mathrm{l})$ were prepared by dilution of a fresh zoospore suspension at $10^{4} \mathrm{ml}^{-1}$ with a test solution to 100 zoospore $\mathrm{ml}^{-1}$. Test solutions included SDW, dilutions from $1 \mathrm{mM}$ purified AI-2 (Omm Scientific Inc, Dallas, TX) and ZFF from different species. To test whether ZFF was heat or freezing labile, ZFFnic boiled for $5 \mathrm{~min}$ or freeze thawed was also included. For determination of the infection threshold of $P$. capsici, the zoospore suspension was diluted in SDW to prepare inocula at $10^{2}, 10^{3}$ or $10^{4} \mathrm{ml}^{-1}$, containing an average of 1,10 , or 100 zoospores per $10-\mu$ drop.

For inoculation with $P$. nicotianae, detached annual vinca leaves were used as described previously [18]. Each leaf was inoculated at 10 sites unless stated otherwise with a $10-\mu$ l drop of single zoospore inocula. Each treatment included six replicate leaves and was done at least three times.

In the $P$. sojae $\times$ lupine phytopathosystem, each cotyledon of lupine plants received one $10-\mu$ l drop of a single zoospore inoculum. Each treatment included 10 cups. Each cup contained 5-10 plants. Inoculated plants were kept in a moist chamber at $23^{\circ} \mathrm{C}$ in the dark overnight, then at a $10 \mathrm{~h} / 14 \mathrm{~h}$ day/night cycle until symptoms appeared. Plants with damping-off symptoms were recorded as dead plants. Each assay was repeated twice.

Similarly, for soybean and pepper plant inoculation, two $10-\mu \mathrm{l}$ drops of an inoculum containing single or multiple zoospores were placed on the hypocotyls of each plant which was laid on its side in a moist chamber. Inoculated plants were kept in the dark overnight and then placed upright in a growth chamber at $26^{\circ} \mathrm{C}$ until symptoms appeared. For soybean, each treatment included at least 3 replicate pots containing 7-9 plants and was repeated twice. For pepper plants, each inoculation was performed in 6 replicate pots containing 3-8 plants.

\section{Microscopy of zoospore activity}

To determine zoospore responses to ZFF and other chemicals, $30 \mu \mathrm{l}$ zoospore suspensions at $10^{4}$ zoospores $\mathrm{ml}^{-}$ ${ }^{1}$ were added to $120 \mu \mathrm{l}$ of a test solution in a well on a depression slide to obtain a density of $2 \times 10^{3}$ zoospores $\mathrm{ml}^{-1}$. Test solutions included fresh or treated (boiled or freeze/thawed) ZFF, a serial dilution from purified AI-2 at $1 \mathrm{mM}$, or SDW. Each test contained two replicate wells per treatment and was repeated once. The slides were placed on wet filter paper in $10-\mathrm{cm}$ Petri dishes and incubated at $23^{\circ} \mathrm{C}$. Zoospore behaviors including encystment, aggregation, germination and differentiation in three random fields in each well were examined with an IX71 inverted microscope (Olympus America Inc., 
Pennsylvania, USA) after overnight incubation. Images were captured with the Image-Pro ${ }^{\circ}$ Plus software version 5.1 (Media Cybernetics, Inc, Maryland, USA).

\section{Transient RPI gene silencing mediated by dsRNA and RT- PCR analysis}

The procedure was adopted from that for P. infestans [41]. To obtain a template for preparation of sense and antisense RNAs by transcription, two pairs of primers containing the T7 RNA polymerase promoter in their forward or reverse sequences were designed for amplification of a partial RPI sequence extracted from the $P$. capsici genome http://genome.jgi-psf.org/PhycaF7/PhycaF7.home.html. These primers were dsRPIPcapF: 5'CAA GCT AAG CAG CTC ATC GCC CA-3'; dsRPIPcapRT7: 5'-GTA ATA CGA CTC ACT ATA GGG CAA CAG GCA CCC CCT GGG TCC A-3'; dsRPIPcapR: 5'CAA CAG GCA CCC CCT GGG TCC A-3'(TGGACCCAGGGGGTGCCTGTTG); and dsRPIPcapFT7: 5'-GTA ATA CGA CTC ACT ATA GGG CAA GCT AAG CAG CTC ATC GCC CA-3'. Concentrated PCR amplicons were transcribed to produce sense and antisense RNAs using Megascrit RNAi kit (Ambion). Both sense and anti-

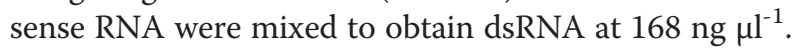

To silence RPI, $P$. capsici protoplasts were transfected with the dsRNA. For each transfection, $24 \mu \mathrm{l}$ of dsRNA $(4 \mu \mathrm{g})$ was dried under vacuum $(20-30 \mathrm{~min})$ and then suspended in $10 \mu \mathrm{l}$ PEG and $0.8 \mathrm{M}$ mannitol solutions, respectively then incubated with $10 \mu \mathrm{l}$ Lipofectin (Invitrogen) for 15 min prior to mixing with $20 \mu \mathrm{l}$. capsici protoplasts. Protoplasts were prepared using a modified transformation protocol for P. sojae [50]. After further incubation for $24 \mathrm{~h}$ at $23^{\circ} \mathrm{C}$, the mixture was transferred to $200 \mathrm{ml}$ pea broth with ampicillin and vancomycin then $4 \mathrm{ml}$ was transferred into each well of 12-well plates.

To determine RPI expression in dsRNA-treated lines, mycelia from each well (line) were subcultured and extracted for RNA on day 7 using the Qiagen RNeasy plant kit. RNA was prepared from the lines before $\left(T_{0}\right)$ and two weeks after transfer $\left(\mathrm{T}_{1}\right)$ as well as from the wild type culture. All the RNAs were treated with the RNase-Free DNAase Set (Qiagen), quantified and subjected to reverse transcription using the SuperScript III Reverse Transcriptase kit (Roche) followed by PCR using primers RPIPcapF: 5'- CAG ACG TCG CAG ATA CTA TTA ACC A-3'; and RPIPcapR: 5'-CTC CAG GAA GTA ATG CAT GAC ACA A-3' for RPI and actin housekeeping gene primers [50] for an endogenous control. The PCR products were then analyzed by electrophoresis.

\section{Detection of AHL activity}

Acyl-homoserine lactone (AHL) activity was determined with an Agrobacterium tumefaciens AHL reporter strain (KYC55/pJZ410/pJZ384/pJZ372) [46]. The reporter strain cannot produce AHLs but has plasmids containing a traI-lacZ reporter fusion and the regulator TraR driven by a T7 expression system. In the presence of exogenous AHLs, the over-expressed $\mathrm{TraR}$ activates the reporter fusion, resulting in production of $\beta$-galactosidase. The reporter can detect a broad range of AHLs ranging from 4- to 18-carbon acyl moieties at nanomolar levels [46]. We monitored LacZ activity by observing X-gal hydrolysis colorimetrically in the culture plates [51] and quantified the activity using the lactose analog ONPG (orthonitrophenylgalactopyranoside) in a spectrophotometric assay [46]. ZFFnic and ZFFsoj from different zoospore suspensions, their ethyl acetate extracts, four positive controls (N-hexanoyl-, N-octanoyl-, N-decanoyl-, and dodecanoyl-DL-homoserine lactones (Sigma-Aldrich, Atlanta, Georgia, US) and a negative control (SDW) were included in the experiments. All AHLs were assessed at concentrations of $10 \mathrm{nM}$ and $100 \mathrm{nM}$.

In plate assays, $10 \mu \mathrm{l}$ of ZFF, a synthetic AHL or SDW was injected at the center of the test plates with a pipette once the overlay was set. After incubation at $28^{\circ} \mathrm{C}$ for 2 days, LacZ activity was measured by the diameter of the blue area in test plates. The experiments were performed four times, and each experiment had two replicate plates. In spectrophotometric assays, the reporter was pre-induced in the AT medium containing antibiotics and stored at $-80^{\circ} \mathrm{C}$. The thawed cells were resuspended in AT medium (1:1000). A 200- $\mu$ l aliquot of ZFF or SDW, or $50 \mu \mathrm{l}$ of synthetic AHL was added to glass tubes containing $2 \mathrm{ml}$ suspension. Cultures were grown on a shaker at $28^{\circ} \mathrm{C}$ until $\mathrm{OD}_{600}=1.0(1.5$ days). The bacterial cells in each tube were lysed by the addition of $800 \mu \mathrm{l}$ of $\mathrm{Z}$ buffer, $20 \mu \mathrm{l}$ of $0.05 \%$ SDS and $30 \mu \mathrm{l}$ of chloroform followed by vortexing. LacZ activity was measured using the Miller Unit at $\mathrm{OD}_{420}$ for the supernatant after the reaction with $100 \mu \mathrm{l}$ of ONPG was ended by $1 \mathrm{M} \mathrm{Na}_{2} \mathrm{CO}_{3}$. The experiment was carried out in replicate and performed twice.

\section{Statistical analysis}

Data from independent experiments were processed and statistically analyzed using ANOVA in Excel. All Pvalues were determined based on one-way ANOVA unless otherwise stated.

\section{Acknowledgements}

The authors are indebted to Dr. Jun Zhu at the University of Pennsylvania School of Medicine for providing AHL-reporter strain KYC55 and the assay protocol. This work was supported in part by grants to $\mathrm{CH}$ from USDA-NIFA (2005-51101-02337 and 2010-51181-21140) and to ZSZ from NIAID/NIH (1R01Al058146) as well as an oomycete genomics and bioinformatics training fellowship to PK, supported by the NSF Research Collaboration Networks grant to BMT for the oomycete community. 


\section{Author details}

'Department of Plant Pathology, Physiology and Weed Science, Virginia Polytechnic Institute and State University, Virginia Beach, VA 23455-3363, USA. ${ }^{2}$ Virginia Bioinformatics Institute, Virginia Polytechnic Institute and State University, Blacksburg, VA 24061-0477, USA. ${ }^{3}$ The Barnett Institute and Department of Chemistry and Chemical Biology, Northeastern University, Boston, MA 02115, USA.

\section{Authors' contributions}

PK conceived of the study, carried out the experiments and drafted the manuscript. BMT identified the RPI gene sequence, participated in designing experiments for RPI cloning, silencing and expression, and helped interpret the data and write the paper. PAR maintained cultures of isolates used in all experiments and participated in drafting and editing the manuscript. BWKL conducted chemical analysis of Al-2 in ZFFs and participated in drafting and editing the manuscript. ZSZ has been involved in design and coordination of this study as well as editing of the manuscript. $\mathrm{CH}$ participated in conceiving of the study, drafting and editing the manuscript. All authors read and approved the final manuscript.

Received: 1 September 2010 Accepted: 7 December 2010 Published: 7 December 2010

\section{References}

1. Erwin DC, Ribeiro OK: Phytophthora Diseases Worldwide. St Paul, MN, USA: APS Press; 1996.

2. Dick MW: Keys to Pythium. Reading, U. K.: University of Reading; 1990.

3. Deacon JW, Donaldson SP: Molecular recognition in the homing responses of zoosporic fungi, with special reference to Pythium and Phytophthora. Mycol Res 1993, 97:1153-1171.

4. Erwin DC, Bartnicki-Garcia S, Tsao PH: Phytophthora: Its Biology, Taxonomy, Ecology, and Pathology. St. Paul, Minnesota, USA: The American Phytopathologcal Society; 1983.

5. Judelson HS, Blanco FA: The spores of Phytophthora: Weapons of the plant destroyer. Nature Reviews Microbiology 2005, 3(1):47-58

6. Hong CX, Moorman GW: Plant pathogens in irrigation water: challenges and opportunities. Critical Reviews in Plant Sciences 2005, 24:189-208.

7. MacDonald JD, Abeliovich A, Lagunas-Solar M, Faiman D, Kabashima J: Treatment of irrigation effluent water to reduce nitrogenous contaminants and plant pathogens. BARD Scientific Reports 1997, 1-47.

8. Bush EA: Characterization of Phytophthora species in recycled irrigation water at a container nursery in southwestern Virginia. Blacksburg, VA, USA: Virginia Polytechnic Institute and State University; 2002.

9. Kong P, Hong CX, Jeffers SN, Richardson PA: A species-specific polymerase chain reaction assay for rapid detection of Phytophthora nicotianae in irrigation water. Phytopathology 2003, 93(7):822-831.

10. Reid B, Morris BM, Gow NAR: Calcium-dependent, genus-specific, autoaggregation of zoospores of phytopathogenic fungi. Exp Mycol 1995 19(3):202-213

11. Ko WH, Chan MJ: Aggregation of Phytophthora capsici zoospores and their interaction with zoospores of $P$. palmivora. Journal of General Microbiology 1974, 80:3

12. Latijnhouwers $M$, Ligterink W, Vleeshouwers V, van West P, Govers F: A G alpha subunit controls zoospore motility and virulence in the potato late blight pathogen Phytophthora infestans. Mol Microbiol 2004 51(4):925-936

13. Kamoun $S$, vanWest $P$, deJong AJ, deGroot KE, Vleeshouwers V, Govers F: A gene encoding a protein elicitor of Phytophthora infestans is downregulated during infection of potato. Molecular Plant-Microbe Interactions 1997, 10(1):13-20.

14. von Broembsen SL, Deacon JW: Calcium interference with zoospore biology and infectivity of Phytophthora parasitica in nutrient irrigation solutions. Phytopathology 1997, 87(5):522-528.

15. Fraedrich SW, Tainter FH, Miller AE: Zoospore inoculum density of Phytophthora cinnamomi and the infection of lateral root-tips of shortleaf and loblolly-pine. Phytopathology 1989, 79(10):1109-1113.

16. Mitchell DJ, Kannwischer-Mitchell ME: Relationship of inoculum density of Phytophthora species to disease incidence in various hosts. In Phytophthora: Its Biology, Taxonomy, Ecology, and Pathology. Edited by: Erwin DC, Bartnicki-Garcia S, Tsao PH. St. Paul, MN, USA: APS Press; 1983:259-269.
17. Clarke DD: Factors affecting the development of single zoospore colonies of Phytophthora infestans. Tran Br Mycol Soc 1966, 49:177-184.

18. Kong P, Hong CX: Zoospore density-dependent behaviors of Phytophthora nicotianae are autoregulated by extracellular products. Phytopathology 2010, 100(7):632-637.

19. Irving HR, Griffith JM, Grant BR: Calcium efflux associated with encystment of Phytophthora palmivora zoospores. Cell Calcium 1984, 5(5):487-500.

20. Warburton AJ, Deacon JW: Transmembrane $\mathrm{Ca}^{2+}$ fluxes associated with zoospore encystment and cyst germination by the phytopathogen Phytophthora parasitica. Fungal Genetics and Biology 1998, 25(1):54-62

21. Kong P, Lee BWK, Zhou ZS, Hong CX: Zoosporic plant pathogens produce bacterial autoinducer-2 that affects Vibrio harveyi quorum sensing. FEMS Microbiology Letters 2010, 303(1):55-60.

22. Gubler F, Hardham AR, Duniec J: Characterizing adhesiveness of Phytophthora cinnamomi zoospores during encystment. Protoplasma 1989, 149:24-30.

23. Deacon JW: Ecological implications of recognition events in the preinfection stages of root pathogens. New Phytologist 1996, 133(1):135-145.

24. von Broembsen SL, Deacon JW: Effects of calcium on germination and further zoospore release from zoospore cysts of Phytophthora parasitica. Mycological Research 1996, 100:1498-1504

25. Bassler BL: How bacteria talk to each other: regulation of gene expression by quorum sensing. Current Opinion in Microbiology 1999, 2(6):582-587.

26. Winzer K, Hardie KR, Williams P: LuxS and autoinducer-2: Their contribution to quorum sensing and metabolism in bacteria. Advances in Applied Microbiology 2003, 53:291.

27. Vendeville A, Winzer K, Heurlier K, Tang CM, Hardie KR: Making 'sense' of metabolism: Autoinducer-2, LuxS and pathogenic bacteria. Nat Rev Microbiol 2005, 3(5):383-396.

28. Hauck T, Hubner Y, Bruhlmann F, Schwab W: Alternative pathway for the formation of 4,5-dihydroxy-2,3-pentanedione, the proposed precursor of 4-hydroxy-5-methyl-3(2H)-furanone as well as autoinducer-2, and its detection as natural constituent of tomato fruit. Biochimica Et Biophysica Acta-General Subjects 2003, 1623(2-3):109-119.

29. Gao M, Teplitski M, Robinson JB, Bauer WD: Production of substances by Medicago truncatula that affect bacterial quorum sensing. Molecular Plant-Microbe Interactions 2003, 16(9):827-834

30. Teplitski M, Chen HC, Rajamani S, Gao M, Merighi M, Sayre RT, Robinson JB, Rolfe BG, Bauer WD: Chlamydomonas reinhardtii secretes compounds that mimic bacterial signals and interfere with quorum sensing regulation in bacteria. Plant Physiology 2004, 134(1):137-146

31. Taga ME, Semmelhack JL, Bassler BL: The LuxS-dependent autoinducer Al2 controls the expression of an ABC transporter that functions in Al-2 uptake in Salmonella typhimurium. Molecular Microbiology 2001, 42(3):777-793

32. Sun JB, Daniel R, Wagner-Dobler I, Zeng AP: Is autoinducer-2 a universal signal for interspecies communication: a comparative genomic and phylogenetic analysis of the synthesis and signal transduction pathways? BMC Evol Biol 2004, 4(36).

33. Bassler BL, Greenberg EP, Stevens AM: Cross-species induction of luminescence in the quorum-sensing bacterium Vibrio harveyi. J of Bacteriol 1997, 179(12):4043-4045.

34. Federle MJ, Bassler BL: Interspecies communication in bacteria. J Clin Invest 2003, 112(9):1291-1299.

35. Higgins DA, Pomianek ME, Kraml CM, Taylor RK, Semmelhack MF, Bassler BL: The major Vibrio cholerae autoinducer and its role in virulence factor production. Nature 2007, 450(7171):883-886

36. Rader BA, Campagna SR, Semmelhack MF, Bassler BL, Guillemin K: The quorum-sensing molecule autoinducer 2 regulates motility and flagellar morphogenesis in Helicobacter pylori. Journal of Bacteriology 2007, 189(17):6109-6117

37. Kozlova EV, Popov VL, Sha J, Foltz SM, Erova TE, Agar SL, Horneman AJ, Chopra AK: Mutation in the S-ribosylhomocysteinase (luxS) gene involved in quorum sensing affects biofilm formation and virulence in a clinical isolate of Aeromonas hydrophila. Microbial Pathogenesis 2008, 45(56):343-354

38. Surette MG, Bassler BL: Quorum sensing in Escherichia coli and Salmonella typhimurium. Proceedings of the National Academy of Sciences of the United States of America 1998, 95(12):7046-7050. 
39. Chen X, Schauder S, Potier N, Van Dorsselaer A, Pelczer I, Bassler BL, Hughson FM: Structural identification of a bacterial quorum-sensing signal containing boron. Nature 2002, 415(6871):545-549.

40. Waters CM, Bassler BL: Quorum sensing: cell-to-cell communication in bacteria. Annu Rev Cell Dev Biol 2005, 21:319-346.

41. Whisson SC, Avrova AO, Van West P, Jones JT: A method for doublestranded RNA-mediated transient gene silencing in Phytophthora infestans. Molecular Plant Pathology 2005, 6(2):153-163.

42. Broughton WJ, Jabbouri S, Perret X: Keys to Symbiotic Harmony. J Bacteriol 2000, 182(20):5641-5652

43. Riedlinger J, Schrey SD, Tarkka MT, Hampp R, Kapur M, Fiedler H-P: Auxofuran, a novel metabolite that stimulates the growth of fly agaric, is produced by the Mycorrhiza helper bacterium Streptomyces strain AcH 505. Appl Environ Microbiol 2006, 72(5):3550-3557.

44. Zentmyer GA: Bacterial stimulation of sporangium production in Phytophthora cinnamomi. Science 1965, 150(3700):1178-1179.

45. Joint I, Tait K, Callow ME, Callow JA, Milton D, Williams P, Camara M: Cellto-cell communication across the prokaryote-eukaryote boundary. Science 2002, 298:1207.

46. Zhu J, Chai YR, Zhong ZT, Li SP, Winans SC: Agrobacterium bioassay strain for ultrasensitive detection of $\mathrm{N}$-acylhomoserine lactone-type quorumsensing molecules: Detection of autoinducers in Mesorhizobium huakuii. Applied and Environmental Microbiology 2003, 69(11):6949-6953.

47. Gallegly ME, Hong C: Phytophthora: Identifying Species by Morphology and DNA Fingerprints. St. Paul: APS Press; 2008.

48. Hong CX, Gallegly M, Richardson P, Kong P, Moorman G, Lea-Cox J, Ross D: Phytophthora irrigata and Phytophthora hydropathica, two new species from irrigation water at ornamental plant nurseries. Phytopathology 2008, 98(6):S68-S68.

49. Ribeiro OK: A Source Book of the Genus Phytophthora. J Cramer Press, Germany 1978

50. Dou D, Kale SD, Wang X, Chen Y, Wang Q, Wang X, Jiang RHY, Arredondo FD, Anderson RG, Thakur PB, et al: Conserved c-terminal motifs required for avirulence and suppression of cell death by Phytophthora sojae effector Avr1b. Plant Cell 2008, 20(4):1118-1133.

51. Szenthe A, Page WJ: Quorum sensing in Agrobacterium tunmefaciens using $\mathrm{N}$-oxo-acyl-homoserine lactone chemical signal. In Tested studies for laboratory teaching. Volume 24. Edited by: O' Donnell MA. Proceedings of 24th Workshop/Conference of the Association for Biology Laboratory Education (ABLE); 2003:145-152[http://www.ableweb.org/volumes/vol-24/10szenthe.pdf].

doi:10.1186/1471-2180-10-313

Cite this article as: Kong et al: Zoospore interspecific signaling promotes plant infection by Phytophthora. BMC Microbiology 2010 10:313.

\section{Submit your next manuscript to BioMed Central and take full advantage of:}

- Convenient online submission

- Thorough peer review

- No space constraints or color figure charges

- Immediate publication on acceptance

- Inclusion in PubMed, CAS, Scopus and Google Scholar

- Research which is freely available for redistribution 